mentioned was perhaps a subordinate 'Keeper of the Prison' (sa'wly en khenret). In Dynasties XII-XIII 'Scribes of the Great Prison' are especially attested. Hayes cit es six 'Directors', ten 'Scribes' and one 'Keeper' in his book. One oinicial, on British Museum Stela 828, tells how ".......His Majesty made me Scribe of the Prison of Trial", later on "...... Scribe of the Great Prison", and eventually “....Scribe of the Royal Records......". The prisons maintained, as would be expected, close links with the Department for Agriculture and the Labour bureau (literally, 'Office of the Provider of People'), as reflected in the new papyrus.

In the Criminal Register of the Great Prison at Thebes, the Brooklyn Papyrus names seventy-six citizens who had absconded from state corvée or like service. It systematically files each person under seven headings, giving as follows : (1) name; (2) distinguishing epithet; (3) sex; (4) resumé of government directive, citing the charge and calling for proceedings under the appropriate clause of the law code; (5) a note, "Here". or. "Brought", or something similar-i.e., the offender is safely in prison or soon will be; (6) statement of completion of the case from the scribe of the Vizier; (7) a final check-mark, "Case closed". No doubt this final laconic note would conclude the records of the butler, baker and Joseph when they left prison over a century later ! The Egyptian authorities seemed invariably to have tracked down their criminals and to have kept long-standing cases open with dogged persistence.

The verso of the Papyrus is equally intriguing, for it lists seventy-nine servants in a large Dynasty XIII Egyptian household (ca. I745 B.C.) of whom forty-five were (mainly Semitic) Asiatics. A few, especially the children, bear purely Egyptian names, but most bear Semitic names. Nearly forty of these people actually bear a (usually) Semitic name followed by the epithet 'who-is-called' and a second, Egyptian, name. This provides' a powerful contemporary parallel for the construction of Joseph's Egyptian name Zaphenath-Paaneah, (to be the subject of a forthcoming study). One or two names in the Brooklyn list are of special interest. One is identical with the later Hebrew name 'Menahem'. Another is actually a 'Shiphr(ah)', later the name of midwife in Ex. i: 15, who thus bore in her time a name already venerable. A third is etymologically comparable with that of Job. The status of some of these servants is a perfect reflection of Joseph's first status in Potiphar's household. In Gen. xxxix. 2, Joseph is a domestic servant 'in the house'-exactly the status hery-per recorded of Semites and Egyptians in the Brooklyn Papyrus and elsewhere. (Note that this is not an exalted title as Yahuda claimed.) Later, in Gen. sxxix. 4, Joseph rose to be Steward in the household, the very common Egyptian title of imy-ra-per.

Although neither main portion of this papyrus directly touches Joseph himself, yet its fascinating background material contributes forcefully to the impression of reality in Gen. xxxix-xl.

School of Archaeology

and Oriental Studies,

K. A. KITCHEN.

University of Liverpool.

\title{
THE DEATH OF STEPHEN
}

The prominent position given by Luke to Stephen's speech in Acts vii is acknowledged by all. So is its connection with Saul's conversion, which is hinted at in vii. $5^{\delta}$. But it is possible that the formal connection made in viii. I between ch. vii and the events of ch. viii covers a very much deeper and larger conception in Luke's mind than is generally realised: that these two chapters with their continuation in ch. ix and onwards draw out the full significance of the death of Christ for all men, not simply as a forecast of the future but as a practical reality.

The starting point of this investigation must be the charge preferred against Stephen. In vi. I I the suborned men accuse Stephen of speaking against the Law; in vi. $13 \mathrm{f}$. the charge is expanded, and the parallel with Jesus made explicitly: (R.S.V.)

"This man never ceases to speak words against this holy place and the Law."

"Jesus of Nazareth will destroy this place, and will change the customs which Moses delivered to us." 
The whole "frame, up" against Stephen is highly suggestive. Why is it that in the Gospel story (Lk. xxii. $66 \mathrm{ff}$.) no mention is made by Luke of the testimony of the false witnesses, although their presence is implied rather inconsequentially in $v$. 71 ? Both Matthew and Mark make much of them at the trial (Mt. xxvi. $59 \mathrm{ff}$. Mk. xiv. $56 \mathrm{ff}$. and cf. the taunt of the bystanders at the crucifixion-Mk. xv. 29 and Mt. xxvii. 40) even though the witnesses were inconsistent and apparently did not succeed in establishing their accusation. Luke omits the false witnesses in the Gospel but introduces them in Acts, not simply to condemn Stephen for his own assertions, but to condemn him as quoting Jesus' declaration against the Temple and the Law. Surely this is not accidental. I suggest that this is the first implicit declaration by Luke of his understanding of Stephen's death and the expansion recorded in Acts viii. Looking back from beyond Pentecost, after the Church had extended throughout the world, Luke sees that Jesus' words quoted by false witnesses were not substantiated till later-he therefore holds over this part of the narrative because the words were to be re-enacted and fulfilled in Stephen's trial and its sequel. For this, I suggest, is the significance of Acts vii and viii :-Luke sees in them the working out of the prophecy which Jesus Himself made, and so the realizing of what was, implicit in His death from the start.

One or two more close parallels between Stephen's death and Jesus' death may now be noted.

I. Stephen's accusation against the Jews (vii. $5 \mathrm{I}-53$ ) is very reminiscent of Jesus' woes against the Lawyers (Lk. xi. 45-52):

(a) The persecution of the Prophets-the attitude of the Jews compared with that of the fathers.

(b) The charge of not keeping the Law.

(c) The hint in xi. $49-51$ of the yet greater murder about to be laid to their charge-made explicit in Acts vii. 52 .

It may be argued that the Gospel passage, placed as it is in the "Travel Document", has little outward connection with the Passion; but the words following this section (Lk. xi. 53) and the setting of the parallel passage in Mt. xxiii suggest such a connection. The attitude of the Pharisees in these verses is very similar to what must have been underlying the attack on Stephen in Acts vi. $10 \mathrm{ff}$.

The reference to the blood of the Prophets being required of this generation must be a prophecy of Jesus' passion. The idea is surely taken up again in the Jews' own acceptance of this prophecy in their 'cry: "His blood be "IKn us..." In Mt. this is recorded in the trial before Pilate, Mt. xxvii. 25. Luke dees $n$ nt record it here-but he does record a very similar saying in Acts v. 28 Iram ?he mouth of the High Priest in his injunction to Peter. It is possible that thic is another instance of Luke deliberately witholding an idea from the Ficspel story trecause it is to come in Acts in consonance with his plan of slirswing the fulfilment of the implications of Christ's death in the life and ex. mansion of the early Church.

2. The weth-known parallel of Acts vii. 56 with Lk. xxii.69.

3. Stegher's rwr, prayers cf. the two words from the Cross which Luke records $x x$ ini. 31 firel 46 (accepting the former as authentic).

4. (?) Slight similarites in diction: dikaios Acts vii. 52 cf. Lk. xxiii. 47 re hurial: Acts viii. 2 and Lk. xxiii. $50 \mathrm{f}$.

My suggestion would be, then, that there is in Luke's mind a connection hetwern Stephen's death and Jesus' death much closer and deeper than is immertiately apparent from the well-known similarities (2) and (3) above. This connection is explained more fully in Stephen's speech with its treatmint of the Temple and the Law. In the speech Luke sees the underlving rebellion of the Jews throughout their history. Jesus passed through vicissitudes similar to those which Abraham, Joseph and Moses endured. He is their Successor and Superseder, so that implicit in His coming is the 1. iection of the religious exclusivism and legalism of the Jews. But even after 1s:us' death the break out is only latent. The death of Stephen makes it effective, as is symbolized in ch. viii with the mission to Samaria and the - nnversion of the Eunuch. This is necessarily but a brief sketch, but some j) sinters have perhaps been given. 